\author{
도심 가로수 뿌리의 융기특성 연구 \\ - 대전 서구 가로수를 대상으로 - \\ 탁승철* · 이시영** \\ "배재대학교 대학원 원예조경학과 · "배재대학교 조경학과
}

\title{
A Study on Root Damage to Street Pavement from the Roots of Roadside Trees in Urban Areas \\ - Focusing on Roadside Trees in Seo-gu, Daejeon City -
}

\author{
Tak, Seong-Cheol ${ }^{*} \cdot$ Lee, Shiyoung ${ }^{*}$ \\ "Dept. of Horticulture \& Landscape Architecture, Graduate School of PaiChai University \\ *Dept. of Landscape Architecture, PaiChai University
}

\begin{abstract}
This study investigated root damage characteristics and correlations between roadside trees and street furniture through the investigation of the root damage conditions and the current status of roadside trees and street furniture in Seo-gu, Daejeon City where the occurrence of pavement uplift is frequent. The study area was divided into six areas by species of trees as Metasequoia glyptostroboides and Platanus occidentalis focusing on the streets that were installed with trees chest height and $8 \mathrm{~cm}$ round planted at the time of the development of the Dunsan-dong Housing Site Development in Seo-gu, Daejeon metropolitan city (1990 1994). The damage rate of roadside protection frames $(95.3 \%)$ was higher than that of curbstones (19.7\%) at the study site. Streets without a protective frame were more likely to have damaged pavement. In addition, the frequency of breakage of protective frames was lowered when a drinking water area was increased to more than a certain level. The frequency of the type of uplift in the sidewalk pavement surfaces is in the order of tail type $>$ mounding type > irregular type, and the frequency of the uplift direction is the highest in Direction $1\left(0 \sim 44^{\circ}\right)$, Direction $2\left(45 \sim 89^{\circ}\right)$, and Direction $3\left(95 \sim 134^{\circ}\right)$ when $180^{\circ}$ of the street direction is based on $90^{\circ}$ parallel to the curbstone. The uplift length is about $31 \sim 60 \mathrm{~cm}$ and it is most often at a height of $3 \sim 6 \mathrm{~cm}$. When comparing the results of uplift deformation, Metasequoia glyptostroboides was found to be higher than the deformation of Platanus occidentalis. In addition, it can be seen that the larger the length, width and height of the ridge, the larger the deformation becomes. The relationship between the diameter at breast height, the dimension of the pavement width, the frequency of the ridge phenomenon and the deformation amount is not necessarily proportional, and there seems to be a gap due to external factors such as soil humidity and planting base. Therefore there is a need for a multi-directional approach in reducing uplift.
\end{abstract}

Key Words: Metasequoia Glyptostroboides, Platanus Occidentalis, Street Physical Elements, Street Uplift Deformation

\footnotetext{
${ }^{+}$: 이 논문은 2018학년도 배재대학교 교내학술연구비 지원에 의하여 수행된 것임(This paper was supported by a research grant from Pai Chai University in 2018).

Corresponding author: Shiyoung Lee, Dept. of Landscape Architecture, Paichai University, Daejeon 35345, Korea, Tel.: +82-42520-5881, E-mail: sylee@pcu.ac.kr
} 


\section{국문초록}

가로수 뿌리융기발생의 빈도가 높은 대전시 서구 내 둔산동택지개발 가로수를 대상으로 뿌리 융기상태와 가로시설 현황조사를 통해 가로수와 가로시설간의 융기특성과 이들 간의 상관관계를 밝히고자 한다. 연구 대상지는 대전광역시 서구를 중심으로 6곳의 메타세쿼이아와 양버즘나무로 선정 조사하였으며, 가로수 뿌리 융기 발생 시 가로수 보호틀 파손율(95.3\%)이 차도경계석파손율(19.7\%)보다 높았다. 또한, 보호덮개가 없는 가로수는 포장면 융기현상 발생 확률이 높으며, 식수대면적이 일정 이상 높아지면 보호틀 파손빈도가 낮아지는 것을 알 수 있었다.

융기형태의 빈도는 꼬리형>마운딩형>불규칙형 순이며, 융기방향의 빈도는 차도경계석과 평행을 기준으로 차량진 행 방향이 $180^{\circ}$ 보도 쪽이 $90^{\circ}$ 로 기준하였을 때 1 방향 $\left(0 \sim 44^{\circ}\right), 2$ 방향 $\left(45 \sim 89^{\circ}\right), 3$ 방향 $\left(90 \sim 134^{\circ}\right)$ 에서 가장 많은 포장면 융기발생이 일어났다. 또한 융기길이는 약 $31 \sim 60 \mathrm{~cm}$ 에서 융기발생이 가장 많이 발생하며, 융기높이는 $3 \sim 6 \mathrm{~cm}$ 에서 발생빈 도가 가장 높다. 융기 변형량 결과를 비교해보면 조사 수종이 주수가 메타세쿼이아가 양버즘나무보다 2주 적음에도 불구하 고 양버즘나무의 변형량보다 약 1.3 배 정도 높게 나타났는데, 이것은 메타세쿼이아가 양버즘나무보다 포장면 융기로 인한 변형량이 높다는 것을 알 수 있다. 또한 융기길이, 융기너비, 융기높이가 클수록 변형량이 높아지는 것을 알 수 있으며, 흉고직경, 보도 폭의 규격, 융기현상의 빈도와 변형량의 관계는 꼭 비례하지 않으며, 토양습도와 식재 기반 등 외부적인 요소로 인해 차이가 있다고 판단되어 융기현상을 저감하기 위한 방법으로 다방향의 개선방안 접근이 필요하다.

주제어: 메타세쿼이아, 양버즘나무, 가로 물리적 요소, 가로 융기 변형량

\section{I. 서론}

도시 가로는 보행자, 자전거이용자, 차량 등이 통행을 하는 장소로 볼 수 있으며, 가로수는 녹음과 그늘을 제공해주고, 공 기정화, 산소제공 등을 통하여 이용자에게 쾌적함을 제공해 주 어 도시요소 중 매우 중요한 역할을 한다.

하지만 최근 가로수 뿌리로 인하여 지자체들이 도시 미관과 조경 등 을 위해 도심 속에 심어 오랜 시간 정성을 들여 가꿔 온 가로수들이 오 히려 사고 위험과 불편을 야기하면서 골머리를 않고 있다. 특히 정기적 인 관리와 함께 다른 곳으로의 이식 등도 고려하고 있지만, 최초 식재 비용보다 수배의 예산이 필요한데다 벌목에 대한 시민 반대여론도 있 어 대책 마련에 고심하고 있다. 이로 인해 가로수 뿌리로 인한 보도블 럭 파손 등으로 보행안전을 위협하면서 민원이 잇따르고 있다 (http://www.kgnews.co.kr/news/articleView.html?idxno=49 3141). 게다가 건조한 도시기후, 오염물질의 증가, 토양표면의 포장 증가 등 주변 환경에 따라 삼림의 수목에 비해 가로수의 생장률이 뚜렷이 저하되고 있으며, 폭이 좁은 보도에의 식재와 누적된 답압으로 인하여 빗물의 지하침투가 어렵고 지하수가 부족하며, 지하토양층 부족과 기증재의 다짐으로 수목의 뿌리 부분이 지표로 생장하면서 뿌리융기현상을 유발하고 있다. 이 러한 현상은 많은 부정적인 영향을 가져오는데 특히 도시미관 을 해칠 뿐 아니라, 포장재의 손상과 높은 굽의 신발을 신은 여 성과 어린이들은 가로수 뿌리에 걸려 넘어지는 안전사고가 발 생하며(Ahn, 2014), 보행자의 통행에 제한이 생기고 가로경관 시설물들의 들림 현상, 파손 등이 발생하여 관리상 많은 문제
점이 나타나고 있는 실정이다.

따라서 본 연구의 목적은 포장면에 뿌리융기발생의 빈도가 높은 대전시 서구 내 가로수의 뿌리 융기상태와 가로시설의 현 황조사를 통하여 가로수와 가로시설 간의 융기특성 및 상관관 계를 밝히고자 대상 가로수종은 뿌리 들뜸 현상의 빈도가 잦 고 그로 인한 보도 융기현상이 발생하는 수종인 메타세콰이어 와 양버즘나무로 선정하였다. 이를 통하여 융기 연구를 실시하 여 효과적인 가로수관리 및 가로수 식재환경 개선 방안을 제시 하고, 뿌리 들뜸으로 인한 가로융기현상에 대하여 효과적인 대 비책을 마련하여 차후 도시미관의 증진과 보행환경개선을 기 대한다.

\section{II. 연구사}

\section{1. 수목 뿌리 특성}

수목의 뿌리는 아래로 자라는 직근, 수직근, 옆으로 자라는 측근, 수평근, 사선으로 자라는 심장근, 물과 양분을 흡수하는 뿌리털이 나있는 모근, 장근, 세근, 단근 등으로 구성되어 있다. 가로수 주변 보도의 융기 현상은 수평근이 자라 굵어지면서 발 생하는 현상이다.

수목의 뿌리는 배의 유근이 발아하여 직근과 측근이 생성되 고 다시 갈라져 세근이 형성된다. 뿌리털은 뿌리의 표면적을 확대시켜 무기염과 수분흡수에 크게 기여하며, 수분이 약간 부 족한듯할 때 왕성하게 발달한다. 예외로는 외생균근을 형성하 
는 나무(소나무류, 참나무류)들은 뿌리털을 형성하지 않는다. 측근은 주근의 내피 안쪽에 있는 내초세포가 분열하여 만들어 진다. 좀 더 자세히 설명하면 내초는 한 층 혹은 서너층의 세포 군으로 세포분열능력이 왕성해져 병층분열과 수층분열에 의 해 내피와 피층을 똟고 주근 밖으로 튀어나와 측근이 된다. 측 근이 튀어 나올 때 주근의 여러 곳에 생기는 상처를 통해 무기 염이 어느 정도 부피유동으로 들어올 수 있고, 병원균이나 박 테리아도 침입하고, 질소고정 박테리아도 서식하게 된다. 뿌 리의 생장속도는 수종과 계절에 따라 다양하며, 생장방향성은 주근이 측의 굴지성에 영향을 미치고, 뿌리구조가 복잡해질수 록 주근의 영향이 적어진다. 또한 지표면에 수분 공급과 기계 적 힘도 뿌리 생장방향에 영향을 미친다(Lee, 2011). 또한 뿌 리발달정도에 따라 지상부의 생육상태에 영향을 끼치는데 지 상부 생육상태와 지하부 뿌리발달 상태를 구분하여 자연지역 과 인공지역을 비교, 세근이 넓게 발달하는 수종과의 관계를 연구하여 세근의 넓게 발달하는 수종은 공간이 협소한 곳보다 는 넓은 자연지역이 생육에 유리하다는 결론을 제시하였다 (Hong et al., 2012). 이처럼 뿌리는 수목의 생육에 매우 밀접한 관계가 있고, 인간의 편의와 쾌적함을 위해서 함부로 해서는 안 되며, 가로수 주변 융기현상을 조사하기 앞서 뿌리의 생장 특성을 알아보고 수목과 인간이 공존할 수 있는 연구를 하고자 한다(Figure 1 참조).

\section{2. 대상 가로수종 근계 특성}

\section{1) 메타세쿼이아}

낙엽침엽교목으로 생장이 아주 빠른 속성수이며, 싹트는 힘 이 왕성하여 전정에도 강하고 이식도 양호하며 (국립수목원 국 가생물종지식정보: 식물, www.forest.go.kr), 원산지에서는 수 고 $35 \mathrm{~m}$ 까지 자라고 수피는 회색빛을 떤 갈색이며, 세로로 벗겨 진다. 가지는 옆으로 퍼지고 잎은 두 줄로 마주 나며, 선모양이 다(국립중앙과학관 식물정보, www.namu.wiki).

근계의 갈라짐은 중간형으로 뿌리털은 성기게 자라며, 뿌리

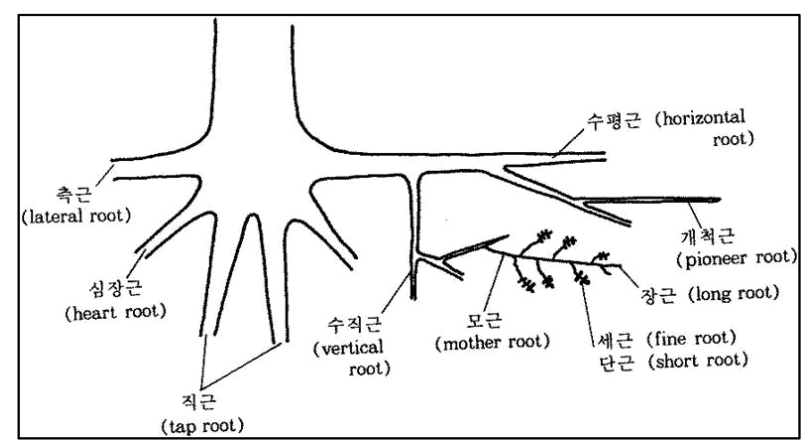

Figure 1. Structure of tree roots Source: 수목생리학(2011)
돌림 뒤 발근성이 아주 높고 근계의 지지력이 크다. 생김새는 중간이거나 큰 지름이 사출근, 수하근형이고 잔뿌리는 촘촘하 며, 수평분포는 집중형이고 잔뿌리는 두껍다. 식재 적기는 $3 \sim 4$ 월이며, 생장이 빠르고 토양은 약간 습한 적윤성에 식질양토의 토성에 적합하고 약산성, 경도는 중간 정도가 적합하다. 세근의 분기는 빠르며 주근의 생장이 양호하고, 형태는 삼나무형으로 표층부분이 밀생되면서 점차 아래로 갈수록 수직형, 직근형으 로 형성되는 것이 특징이다. 중, 대경의 근계형상이 주를 이루 며 세근의 밀생되고 비후형여서 이식에 강하고, 비교적 근계의 지속이 오래 유지되는 편이다. 근단의 직경은 $0.4 \sim 0.5 \mathrm{~mm}$ 정도 이며, 소나무류에 비해서 얇고 긴 편이고, 근의 분기와 생장이 왕성하고 수직근과 직근은 심부에 달하고 수평근은 표층부에 밀생되어 생성된다. 파라솔형의 세근은 굵고 큰 대경의 근계에 모여 붙고 표층에 많다. 소, 중경근의 분기는 적지만 뿌리는 깊 고 근계의 지속력은 큰 편이다(Noburu, 1979).

\section{2) 양버즘나무}

플라타너스(Eastern Sycamore Family Bottonwood)라고도 하며, 학명은 'Platanus occidentalis L.'이다. 북아메리카 원산의 낙엽 대교목으로, 수피는 세로로 갈라지면서 작은 조각으로 떨 어지고 잎은 마주나며, 넓은 난형으로 3 5갈래로 얕게 갈라지 고, 가장자리는 밋밋하거나 드문드문 톱니가 있다(국립생물자 원관 생물다양성정보, www.nibr.go.kr). 뿌리의 형상은 중, 대 경의 수평근, 수직근과 직근이 주를 이룬다. 버즘나무의 근계와 형태가 비슷하고 세근과 근모는 소생형이며, 소, 중경근 보다는 다경근과 특대경근의 근계의 형태를 나타내며, 굴곡이 많다. 이 식에 있어서는 교섭을 충분히 하지 않으면 분형태가 잘 이루어 지지 않으며 쉬운 편이며, 시기는 2 3월이나 10 11월이 뿌리 의 활착이 유리하여 이식하기 좋고, 토양은 적윤성, 약산성이 며, 약간의 통기가 되고 찰흙이 포함된 식성양토의 성질이 뿌 리에 적합하다. 뿌리의 질은 딱딱하며 부러지기 쉽고 부패하기 쉽다. 표층에 있는 중경근은 로프형태로 길게 멀리 뼏고 있으 며, 다수가 집중적으로 위치에 있는 것이 특징이다(Noburu, 1979). 이런 근계형태로 인하여 가로수로 조성 시 뿌리 들뜸으 로 인한 보도 융기현상이 일어나고 있는 실정이며, 이러한 근 계형상을 고려하여 연구를 하고자 한다(Table 1 참조).

Table 1. Roadside trees root characteristics

\begin{tabular}{c|c|c}
\hline Division & $\begin{array}{c}\text { Metasequoia } \\
\text { glyptostroboides }\end{array}$ & Platanus occidentalis \\
\hline Root characteristics & Shallow rooted & Middle depth rooted \\
\hline Effective depth of soil & $1.0 \mathrm{~m}$ & $1.5 \mathrm{~m}$ \\
\hline Effective rhizome scope & $4.5 \mathrm{~m}$ & $4.5 \mathrm{~m}$ \\
\hline
\end{tabular}

Source: Asan city street tree composition and management ordinance(2016) 


\section{III. 연구 방법}

\section{1. 연구 대상지}

본 연구는 가로수의 생육특성과 가로현황 및 융기특성을 조 사- 분석하였다. 연구에 들어가기에 앞서 가로와 가로수의 정 의, 도로와 가로수의 위치관계, 가로수 식재에 관한 연구, 가로 수 뿌리 들뜸으로 인한 융기현상에 관한 수목뿌리의 특성, 가 로융기특성, 보도 포장 특성을 연구하였으며, 대상 가로수종인 메타세쿼이아와 양버즘나무의 근계 특성에 대하여 검토한 후 선행연구를 통하여 뒷받침할 수 있는 이론을 정립하였다. 한편 연구의 대상지인 대전광역시 서구 둔산동은 상권과 거주지역 이 밀집되어 있는 대표적인 격자형 계획도시이며, 인구밀도와 유동인구가 매우 높아 가로현황의 조사대상지에 적합하다고 판단되어 서구 둔산동 일대를 중심으로 서구청 자료를 통한 예 비조사를 실시하여 포장면 융기발생한 곳의 위치를 도면화하 여 현장조사를 실시한 후 선정하였다. 또한, 둔산동 택지개발 (1990 1994년)시 규격 흉고직경 8cm의 수목을 식재 한 가로 수 중 뿌리 들뜸으로 인한 보도 융기현상이 많이 발생하는 수 종인 메타세쿼이아와 양버즘나무를 대상수종으로 선정하였다.

Figure 2의 (1) (3)은 메타세쿼이아의 대상지이며, (4) (6)은 양버즘나무의 대상지이다. 흉고직경 $20 \mathrm{~cm}$ 이상으로 최 초 식재 후 뿌리가 활착한 시점으로 약 20년 이상 경과기간을 지닌 수종이며, 예비조사를 통하여 최근 5년간 뿌리 들뜸 개선 공사를 하지 않은 가로수를 선정하였다.

메타세쿼이아와 양버즘나무는 각각 3 곳을 연구 대상지로 선 정하였다. 메타세쿼이아의 대상지 범위는 문정로 48 번길, 둔산 로 101 번길, 둔산북로 90 번길 총 3 곳이며 문정로 48 번길은 $400 \mathrm{~m}$ 구간이고 총 29 주가 가로수로 식재되어 있다. 둔산로101번길은 $500 \mathrm{~m}$ 구간이며 가로수 총 58 주가 식재되어 있다. 둔산북로 90 번길은 $500 \mathrm{~m}$ 구간이며 가로수가 73 주가 식재되어 있다. 양버즘 나무의 대상지 범위는 한밭대로707번길, 갈마역로, 유등로 총 3 곳을 선정하였으며, 한밭대로707번길은 $200 \mathrm{~m}$ 구간이며 가로 수는 총 38 주가 식재되어 있다. 갈마역로는 일부노선이 보도포 장공사로 인한 정비가 되어 있어서 제외를 하였으며, 총 $600 \mathrm{~m}$ 구간 안에 가로수가 48 주 식재되어 있으며, 유등로는 편도노선 으로 총 $600 \mathrm{~m}$ 구간 안에 가로수는 총 62 주가 식재되어 있다. 가 로수는 총 308주이고, 수종별로 구분하면 메타세쿼이아가 160 주 중 42 주, 양버즘나무가 148 주 중 44 주이다(Table 2 참조).

\section{2. 현장 조사방법}

\section{1) 가로수 조사 실시}

연구의 대상 가로수인 양버즘나무와 메타세쿼이아의 가로 수 특성을 조사하기 위하여 수목의 수종, 흥고직경 $(\mathrm{cm})$, 가로

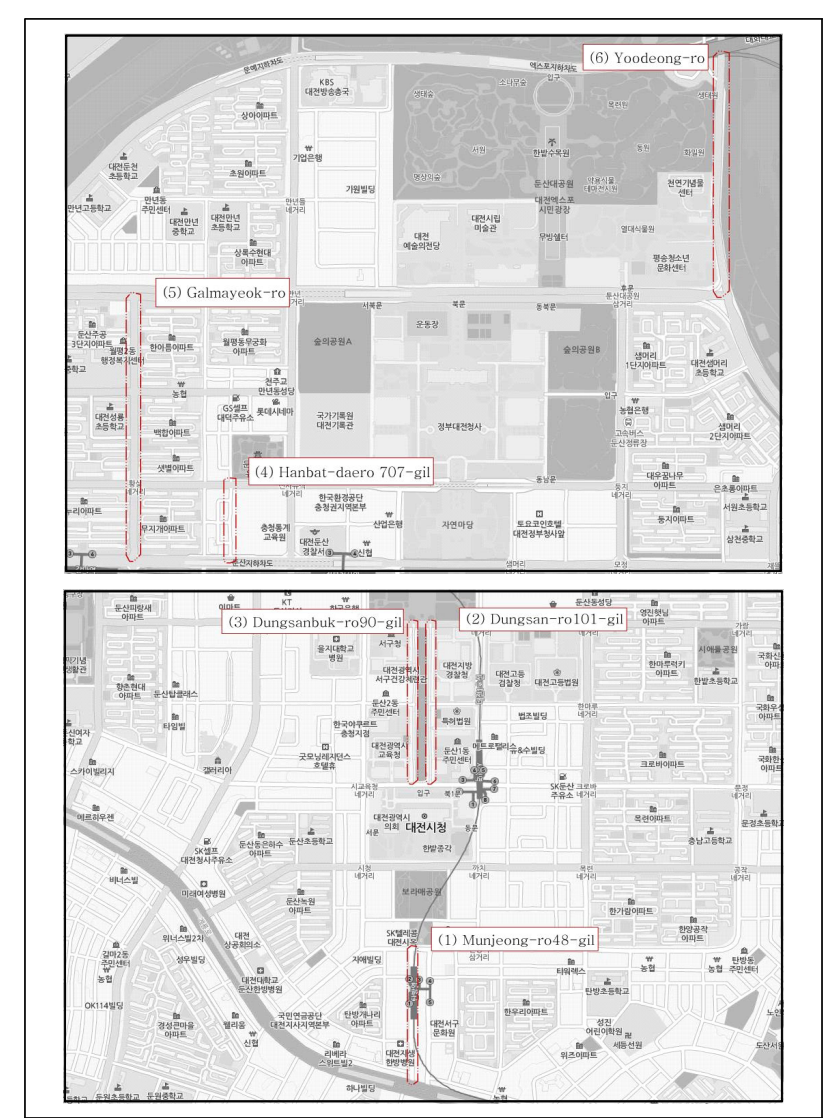

Figure 2. Location of investigating site Source: Http://map.naver.com

Table 2. Investigating site status

\begin{tabular}{c|c|c|c|c|c}
\hline \multirow{2}{*}{ Division } & Investigating site & $\begin{array}{c}\text { Number } \\
\text { of trees }\end{array}$ & $\begin{array}{c}\text { Section } \\
(\mathrm{m})\end{array}$ & $\begin{array}{c}\text { Year } \\
(\mathrm{Y})\end{array}$ & $\begin{array}{c}\text { Elapsde } \\
\text { time } \\
(\mathrm{Y})\end{array}$ \\
\hline \multirow{3}{*}{$\begin{array}{c}\text { Metasequoia } \\
\text { glyptostroboides }\end{array}$} & Munjeong-ro48-gil & 29 & 400 & 1994 & 23 \\
\cline { 2 - 6 } & Dungsan-ro101-gil & 58 & 500 & 1994 & 23 \\
\cline { 2 - 6 } & Dungsanbuk-ro90-gil & 73 & 500 & 1994 & 23 \\
\hline \multirow{2}{*}{$\begin{array}{c}\text { Platanus } \\
\text { occidentalis }\end{array}$} & Hanbat-daero 707-gil & 38 & 200 & 1994 & 23 \\
\cline { 2 - 6 } & Galmayeok-ro & 48 & 600 & 1994 & 23 \\
\cline { 2 - 6 } & Yoodeong-ro & 62 & 600 & 1990 & 27 \\
\hline
\end{tabular}

수간의 거리, 식재위치를 조사하였다. 사전답사와 가로수관리 대장을 통하여 융기현상이 많이 발생하는 구간을 파악하고 선 정하여 수목의 수피와 잎, 수형 등을 살펴 수종을 구분하였다. 흉고직경은 가슴높이 $(1.2 \mathrm{~m})$ 지점에서 흉고직경자 $\mathrm{KDS}$ F10-02D, 말레이시아)를 이용하여 치수를 측정하였으며, 가로수간의 거 리는 융기가 발생한 가로수 양 옆 2 주를 포함하여 총 3 주의 가 로수간 거리를 $50 \mathrm{~m}$ 줄자(코메론 $\mathrm{KMC}-1800$, 한국)를 이용하 여 치수를 잰 후 평균을 내었다. 식재위치는 차도경계석에 맞 대어 조성된 식수대만 있을 경우 1 열 식재로 구분하고, 보도에 도 함께 조성되어 있을 경우를 2 열 식재로 구분하여 융기현상 
이 발생된 가로수의 식재된 위치를 조사하였다(Figure 3 참조).

\section{2) 가로 물리적 요소 조사}

가로 물리적 요소 조사는 보도 폭, 보호틀 형태 및 파손율, 식수대넓이, 보호덮개 유무 및 차도경계석 파손율을 구분하여 조사한다. 보도 폭은 융기현상이 일어난 지점의 보도의 폭을 $50 \mathrm{~m}$ 줄자를 이용하여 실측하였으며, 보호틀의 형태는 기존 대 전시 서구 내 가로수에 이용되는 보호틀의 유형을 참고하여 보 호틀의 크기, 모양, 재질 등을 조사하였으며, 그에 따른 넓이를 측정하였다. 파손율은 식수대 보호틀이 깨지거나 분리되지 않 고 들림 현상만 일어난 형태를 들림, 깨져 분리된 것을 깨짐, 일부 손실된 상태를 파손이라 구분한다. 여기서 들림보다는 깨 짐, 깨짐보다는 파손을 상위 파손형태이며, 파손 시 깨짐과 들 림이 포함되고 깨짐 시 들림이 당연 포함된다고 봐도 무방하며 보호덮개는 있음, 없음을 구분하여 유, 무로 조사하였다.

\section{3) 가로 융기 특성 조사}

융기방향, 융기길이 및 너비, 융기높이, 융기형태의 조사를 통 하여 조사대상 가로수별 융기정도의 변형량을 산정하기 위한 기초연구자료로 활용하였다.

융기방향은 수목 식수대 보호틀을 중심으로 나타나는 방향 과 개수를 수목 보호틀 외부로의 시작점을 기준으로 파악하였 다. 방향은 수목 중심을 기준으로 $360^{\circ}$ 각도기(S. H 곤요메타, 한국)를 이용하여 측정하였으며, 차량 진행방향을 $180^{\circ}$, 차량 진행 반대 방향을 $0^{\circ}$, 보도쪽을 $90^{\circ}$ 로 기준하고, 수목 보호틀 외 부로 나타나는 융기의 방향을 측정하였다.

융기길이 및 너비는 보도 포장면의 융기 길이를 측정하기 위 하여 수목 보호틀 외부로의 시작점을 기준으로 $1 \mathrm{~cm}$ 이상 나타 나는 변형된 최단길이를 줄자로 실측하였으며, 융기너비는 최 대 너비와 최소 너비를 측정하여 평균을 산출하였다. 융기높이 는 보도 포장면의 융기 높이를 측정하기 위하여 레벨측정기를 사용하여 보도 포장면에 발생한 융기에 대하여 조사하였다. 조 사방법은 보도 포장면에 발생된 융기에 최대 높이와 융기현상 이 일어나지 않은 지면과의 차를 이용하여 변형된 높이를 측정 하였다.

융기형태는 입면형태와 평면 형태를 고려하여 수목 보호틀 외부로의 시작점으로부터 선형으로 이어지는 융기형태를 꼬리

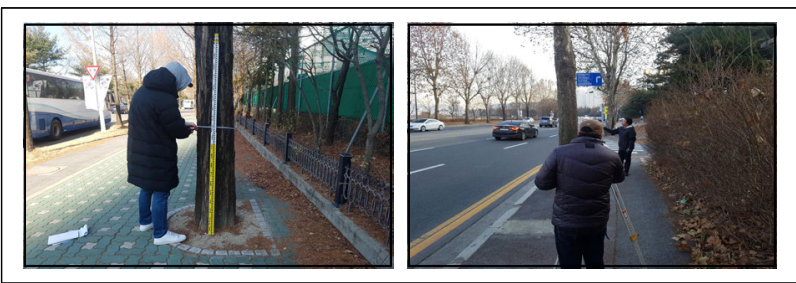

Figure 3. Road side trees and uplift characteristics investigation
형, 언덕모양으로 부풀어 오르는 형상을 한 융기형태를 마운딩 형, 불특정 다수로 불규칙하게 융기현상이 발생된 모양을 불규 칙형으로 구분하였다(Table 3 참조).

\section{3. 분석 방법}

\section{1) 기술 분석}

기술 분석은 기술통계방식으로 최대값, 최소값, 평균 및 백 분율을 산출하였다. 가로수 특성조사에서 수목의 수종은 조사 수목 비율, 흉고직경, 가로수 간의 거리, 식재위치를 분석하였 고, 가로 물리적 요소 조사에서 보도 폭, 보호틀 형태 및 파손 율을 분석하고 식수대 넓이와 보호덮개 유무 및 차도경계석 파 손율을 산출하여 분석하였다.

\section{2) 가로 융기특성}

융기방향, 융기길이 및 너비, 융기높이, 융기형태에 대하여 뿌리 들뜸으로 인한 융기현상이 발생된 정도를 각 요소별로 나 누어 기준하였으며, 최소값과 최대값이 기준의 최소 등급과 최 대 등급에 포함되도록 일정한 간격으로 나누어 구간을 정하 였다. 융기방향은 개수를 1 4개로 구분하고 각도는 수목 중심 을 기준으로 $360^{\circ}$ 각도기를 이용하여 총 8 방향으로 구분하여 측정하였으며, 차량 진행 방향을 $180^{\circ}$, 차량 진행 반대 방향 을 $0^{\circ}$, 보도쪽을 $90^{\circ}$ 로 기준하고 수목 보호틀 외부로 나타나는 융기의 방향을 측정하였다. 융기길이는 $30 \mathrm{~cm}$ 이하, $31 \sim 60 \mathrm{~cm}$, $61 \sim 90 \mathrm{~cm}, 91 \sim 120 \mathrm{~cm}, 121 \sim 150 \mathrm{~cm}, 151 \mathrm{~cm}$ 이상의 기준으로 구분한다. 또한 융기 높이는 $3 \mathrm{~cm}$ 이하, $3 \sim 6 \mathrm{~cm}, 6 \sim 9 \mathrm{~cm}, 9 \sim 12$ $\mathrm{cm}, 12 \mathrm{~cm}$ 이상으로 구분하여 측정하였다(Figure 4 참조).

융기형태는 평면 형태와 입면 형태를 고려하여 꼬리형, 마운 딩형, 불규칙형으로 크게 3가지 형태로 구분하여 측정하였다. 꼬 리형은 수목 보호틀 외부 시작점으로부터 방향을 고려하지 않고 선형으로 융기가 발생한 형태이며, 마운딩형은 포장면 융기발생 이 선형이 아닌 완만한 경사의 언덕 모양을 한 형태이며, 불규 칙형은 수목 보호틀 외부 시작점으로부터 융기가 시작되지 않고 조사대상 가로수 주변에 불규칙한 모양으로 융기가 일어난 형태

Table 3. On-site investing method

\begin{tabular}{c|l|l}
\hline Division & \multicolumn{2}{|c}{ Contents } \\
\hline $\begin{array}{c}\text { Roadside trees } \\
\text { investigation }\end{array}$ & $\begin{array}{l}\cdot \text { Tree species } \\
\cdot \text { Chest diameter }(\mathrm{cm})\end{array}$ & $\begin{array}{l}\text { Distance between roadside } \\
\text { trees }\end{array}$ \\
\hline $\begin{array}{c}\text { Street physical } \\
\text { elements } \\
\text { investigation }\end{array}$ & $\begin{array}{l}\cdot \text { Plant location } \\
\cdot \text { Protection frame type and } \\
\text { breakage rate }\end{array}$ & $\begin{array}{l}\text { Protective cover and drive- } \\
\text { way boundary breakage }\end{array}$ \\
\hline $\begin{array}{c}\text { Street uplift } \\
\text { characteristics } \\
\text { investigation }\end{array}$ & $\cdot$ Uplift direction & $\cdot$ Uplift length and width \\
\hline
\end{tabular}




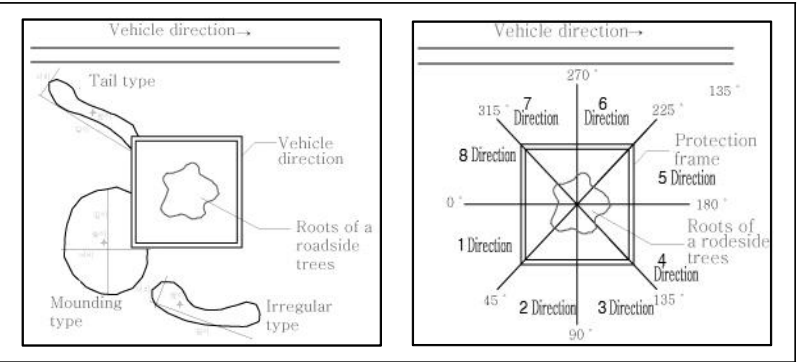

Figure 4. Uplift direction, length and width, height, type

로 기준하고 측정하였다. 융기의 넓이는 융기형태의 길이와 너 비를 형태를 고려하여 직선화하여 면적을 계산하고, 융기 체적 은 산출한 면적에 융기의 최고 높이를 구하였으며, 2 개 이상의 융기체적은 합산하여 변형량을 분석하였다(Table 4 참조).

융기방향, 융기길이 및 너비, 융기높이에 대하여 뿌리 들뜸 으로 인한 융기현상이 발생된 정도를 최소값과 최대값이 최소 등급과 최대등급에 포함되도록 일정한 간격으로 임의로 나누 어 구간을 정하였다.

\section{3) 융기 변형량}

가로수의 뿌리 융기상태와 가로시설의 현황조사를 통하여 가로수와 가로시설 간의 융기특성 및 상관관계를 밝히고자, 보 도 포장면 변형량은 각 수목별 융기발생 변형을 상대적으로 나 타낸 값으로 개별 포장 변형 면적에 융기높이를 곱하여 구하였 다(Ahn, 2014).

\section{IV. 결과 및 고찰}

\section{1. 가로수 현황}

대상지별 조사수목 비율을 살펴보면 메타세쿼이아는 총 160 주 중 문정로 48 번길 10 주, 둔산로 101 번길 10 주, 둔산북로 90 번 길 22 주가 융기발생 가로수로 조사되었으며, 양버즘나무를 살
Table 4. Uplift characteristics analysis

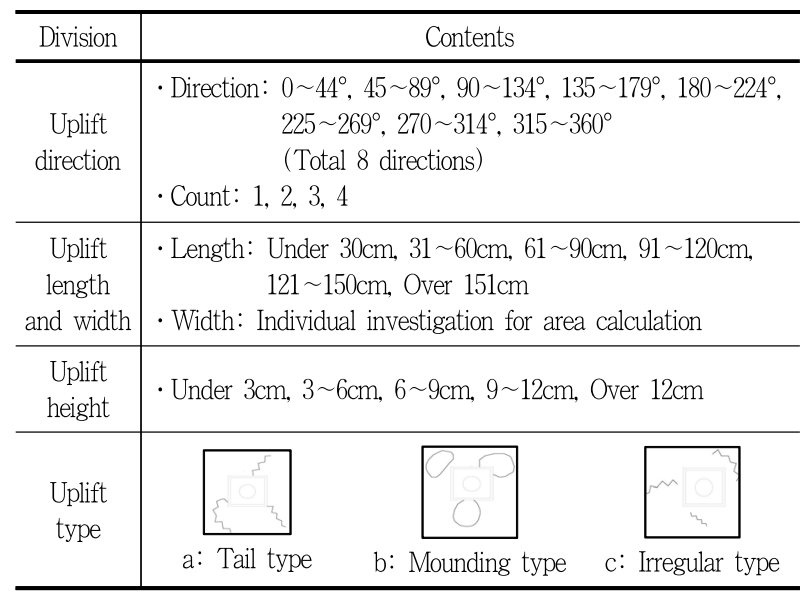

펴보면 총 148 주 중 한밭대로 707 번길은 9주, 갈마역로 14 주, 유등로 21주로 조사되었다.

대상지별 평균 흥고직경은 문정로 48 번길 $29.1 \mathrm{~cm}$, 둔산로 101 번길 $30.9 \mathrm{~cm}$, 둔산북로 90 번길 $29.0 \mathrm{~cm}$ 이며, 양버즘나무를 살펴 보면 한밭대로707번길은 $28.1 \mathrm{~cm}$, 갈마역로 $23.8 \mathrm{~cm}$, 유등로 37.8 $\mathrm{cm}$ 로 조사되었다.

평균 식재간 거리를 살펴보면 메타세쿼이아의 3 곳의 조사대 상지는 문정로48번길은 $7.0 \mathrm{~m}$, 둔산로 101 번길은 $8.1 \mathrm{~m}$, 둔산북로 90 번길은 $7.8 \mathrm{~m}$ 이며, 양버즘나무의 3 곳의 조사대상지는 한밭대 로707번길은 $8.1 \mathrm{~m}$, 갈마역로는 $8.0 \mathrm{~m}$, 유등로도 $8.0 \mathrm{~m}$ 이다. 교 목의 경우 도로의 주위 여건과 위치, 식재수종 생장속도와 수관 폭, 가로수 피해목 등을 고려하여 6 8m를 기준으로 하며, 간 격을 조정할 수 있다는 선행연구에 부합하여 대체적으로 틀에 서 벗어나지 않게 식재 간 거리가 비슷하게 갖추어져 있다. 식 재위치는 메타세쿼이아의 대상지를 살펴보면 문정로48번길은 1 열 식재 9주, 2 열 식재 1주이고, 둔산로 101 번길은 1 열 식재 2 주, 2 열 식재 8 주이며, 둔산북로 90 번길은 1 열 식재 19 주, 2 열 식재 3 주이다. 양버즘나무는 조사대상지 3 곳 모두 1 열 식재만으 로 조성되어 있다(Table 5 참조).

Table 5. Roadside trees investigation analysis

\begin{tabular}{c|c|c|c|c|c|c}
\hline \multirow{2}{*}{ Division } & \multicolumn{3}{|c|}{ Metasequoia glyptastroboides } & \multicolumn{3}{|c}{ Platanus occidentalis } \\
\cline { 2 - 7 } & Munjeong-ro 48-gil & Dungsan-ro 101-gil & Dungsanbuk-ro 90-gil & Hanbat-daero 707-gil & Galmayeok-ro & Yoodeong-ro \\
\hline $\begin{array}{c}\text { Roadside trees } \\
\text { investigation rate(\%) }\end{array}$ & $\begin{array}{c}34.4 \\
(10 / 29)\end{array}$ & $\begin{array}{c}17.2 \\
(10 / 58)\end{array}$ & $\begin{array}{c}30.1 \\
(22 / 73)\end{array}$ & $\begin{array}{c}23.6 \\
(9 / 38)\end{array}$ & $\begin{array}{c}29.1 \\
(14 / 48)\end{array}$ & $\begin{array}{c}33.8 \\
(21 / 62)\end{array}$ \\
\hline $\begin{array}{c}\text { Average chest } \\
\text { diameter(cm) }\end{array}$ & 29.1 & 30.9 & 29.0 & 28.1 & 23.8 & 37.8 \\
\hline $\begin{array}{c}\text { Average distance } \\
\text { between roadside trees(m) }\end{array}$ & 7.0 & 8.1 & 7.8 & 8.1 & 8.0 & 8.0 \\
\hline Plant location & $\begin{array}{l}1 \text { row:9 } \\
2 \text { row:1 }\end{array}$ & $\begin{array}{l}1 \text { row:2 } \\
2 \text { row:8 }\end{array}$ & $\begin{array}{c}1 \text { row:19 } \\
2 \text { row:3 }\end{array}$ & 1 row planting & 1 row planting & 1 row planting \\
\hline
\end{tabular}




\section{2. 가로수 융기발생 현황 및 특성}

\section{1) 융기발생}

본 연구의 조사 대상지 내 가로수는 총 308 주이고 융기현상 이 발생한 조사 수목은 86 주이며, 가로 대상지별 융기발생 한 수목 비율을 살펴보면 메타세쿼이아 가로수길인 문정로48번길 은 29주 중 10주(34.4\%), 둔산로101번길은 58주 중 10주(17.2\%), 둔산북로 90 번길은 73 주 중 22 주 $(30.1 \%)$ 이며, 양버즘나무는 한 밭대로707번길은 38 주 중 9주(23.6\%), 갈마역로는 48 주 중 14 주 (29.1\%), 유등로는 62주 중 21주(33.8\%)에서 융기가 발생되어 메타세쿼이아는 총 160 주 중 42 주(26.2\%)로 조사되었으며, 양 버즘나무는 총 148주 중 44주(29.7\%)로 조사되었다(Table 6 참조).

\section{2) 융기방향}

수종별 융기방향을 보면 1 개 발생의 주수는 메타세쿼이아는 총 42 주 중에 25 주 발생하였고, 양버즘나무는 총 44 주 중에 26 주 발생하였다. 메타세쿼이아의 2 개 발생의 주수는 총 42 주 중 에 12 주, 양버즘나무는 총 44 주 중에 12 주 발생하였고, 3 개 발 생의 주수는 메타세쿼이아 3 주, 양버즘나무 5 주, 4 개 발생의 주 수는 메타세쿼이아 2주, 양버즘나무 1주로 조사되어 두 수종 에서 1 개 $>2$ 개 $>3$ 개 $>4$ 개 순으로 빈도가 높게 나타났다. 또한, 메타세쿼이아와 양버즘나무의 융기방향별 총 빈도를 살펴보 면 3방향 $\left(90 \sim 134^{\circ}\right)$ 이 가장 빈도가 높으며, 다음으로는 2 방향 $\left(45 \sim 89^{\circ}\right)$ 인 것을 알 수 있다. 이는 1 열 식재의 비율이 압도적 으로 높은 것도 영향이 있으며, 융기 발생 시 차도 쪽이 아닌 보 도 쪽으로 뿌리가 더 쉽게 뻗을 수 있어 뿌리융기현상이 발생 한 것으로 판단된다. 또한 식수대 내 답압과도 영향이 있어 방 향이 보도 쪽에서 점차 차도 쪽으로 갈수록 빈도가 줄어드는 것을 확인할 수 있다(Table 7, 8 참조).

\section{3) 융기길이}

대상지 내 조사를 실시한 메타세쿼이아와 양버즘나무의 융 기길이를 비교해보면 $30 \mathrm{~cm}$ 이하는 메타세쿼이아가 1 개, 양버즘 나무가 6개로 빈도가 가장 적으며, 31 60cm는 메타세쿼이아가 21 개, 양버즘나무가 14 개로 총 35 개로 발생빈도가 가장 높다.

Table 6. The occurrence of root uplifts(\%)

\begin{tabular}{c|c|c|c|c|c|c}
\hline \multirow{2}{*}{ Division } & \multicolumn{2}{|c|}{ Metasequoia glyptostroboides } & \multicolumn{3}{|c}{ Platanus occidentalis } \\
\cline { 2 - 7 } & $\begin{array}{c}\text { Mun } \\
\text { jeong-ro } \\
48-\text {-gil }\end{array}$ & $\begin{array}{c}\text { Dung } \\
\text { san-ro } \\
101-\text {-gil }\end{array}$ & $\begin{array}{c}\text { Dung } \\
\text { sanbuk-ro } \\
90 \text {-gil }\end{array}$ & $\begin{array}{c}\text { Hanbat- } \\
\text { daero } \\
707-\text {-gil }\end{array}$ & $\begin{array}{c}\text { Galma } \\
\text { yeok-ro }\end{array}$ & $\begin{array}{c}\text { Yoo } \\
\text { deong-ro }\end{array}$ \\
\hline $\begin{array}{c}\text { Roadside } \\
\text { trees } \\
\text { investigation } \\
\text { rate(\%) }\end{array}$ & $\begin{array}{c}34.4 \\
(10 / 29)\end{array}$ & $\begin{array}{c}17.2 \\
(10 / 58)\end{array}$ & $\begin{array}{c}30.1 \\
(22 / 73)\end{array}$ & $\begin{array}{c}23.6 \\
(9 / 38)\end{array}$ & $\begin{array}{c}29.1 \\
(14 / 48)\end{array}$ & $\begin{array}{c}33.8 \\
(21 / 62)\end{array}$ \\
\hline
\end{tabular}

Table 7. Uplift direction analysis

\begin{tabular}{c|c|c|c|c|c|c|c}
\hline \multirow{2}{*}{ Division } & \multicolumn{2}{|c|}{ Metasequoia glyptostroboides } & \multicolumn{2}{|c}{ Platanus occidentalis } \\
\cline { 3 - 8 } \multicolumn{2}{c|}{$\begin{array}{c}\text { Mun } \\
\text { jeong-ro } \\
48-\text {-gil }\end{array}$} & $\begin{array}{c}\text { Dung } \\
\text { san-ro } \\
101-\text {-gil }\end{array}$ & $\begin{array}{c}\text { Dung } \\
\text { sanbuk-ro } \\
90 \text {-gil }\end{array}$ & $\begin{array}{c}\text { Hanbat- } \\
\text { daero } \\
707-\text { gil }\end{array}$ & $\begin{array}{c}\text { Galma } \\
\text { yeok-ro }\end{array}$ & $\begin{array}{c}\text { Yoo } \\
\text { deong-ro }\end{array}$ \\
\hline \multirow{2}{*}{1} & EA & 5 & 5 & 15 & 6 & 6 & 14 \\
\cline { 2 - 8 } & $\%$ & 50.0 & 50.0 & 68.1 & 66.7 & 42.8 & 66.7 \\
\hline \multirow{2}{*}{2} & EA & 4 & 2 & 6 & 0 & 7 & 5 \\
\cline { 2 - 8 } & $\%$ & 40.0 & 20.0 & 27.3 & 0 & 50.0 & 23.8 \\
\hline \multirow{2}{*}{3} & EA & 0 & 2 & 1 & 2 & 1 & 2 \\
\cline { 2 - 8 } & $\%$ & 0 & 20.0 & 4.6 & 22.2 & 7.2 & 9.5 \\
\hline \multirow{2}{*}{4} & EA & 1 & 1 & 0 & 1 & 0 & 0 \\
\cline { 2 - 8 } & $\%$ & 10.0 & 10.0 & 0 & 11.1 & 0 & 0 \\
\hline \multirow{2}{*}{ Total } & EA & 10 & 10 & 22 & 9 & 14 & 21 \\
\cline { 2 - 8 } & $\%$ & 100.0 & 100.0 & 100.0 & 100.0 & 100.0 & 100.0 \\
\hline
\end{tabular}

Table 8. Uplift direction by angle analysis

\begin{tabular}{|c|c|c|c|c|c|c|c|}
\hline \multirow{2}{*}{\multicolumn{2}{|c|}{ Division }} & \multicolumn{3}{|c|}{ Metasequoia glyptostroboides } & \multicolumn{3}{|c|}{ Platanus occidentalis } \\
\hline & & \multirow{2}{*}{$\begin{array}{c}\begin{array}{c}\text { Mun } \\
\text { jeong-ro } \\
48-\text { gil }\end{array} \\
4\end{array}$} & \multirow{2}{*}{$\begin{array}{c}\text { Dung } \\
\text { san-ro } \\
101-\text { gil }\end{array}$} & \multirow{2}{*}{$\begin{array}{c}\begin{array}{c}\text { Dung } \\
\text { sanbuk-ro } \\
90 \text {-gil }\end{array} \\
5\end{array}$} & \multirow{2}{*}{\begin{tabular}{|c}
$\begin{array}{c}\text { Hanbat- } \\
\text { daero } \\
707-\text { gil }\end{array}$ \\
5
\end{tabular}} & \multirow{2}{*}{$\begin{array}{c}\begin{array}{c}\text { Galma- } \\
\text { yeok-ro }\end{array} \\
6\end{array}$} & \multirow{2}{*}{\begin{tabular}{|c|}
$\begin{array}{c}\text { Yoo } \\
\text { deong-ro }\end{array}$ \\
1
\end{tabular}} \\
\hline $0 \sim 44^{\circ}$ & EA & & & & & & \\
\hline 1direction & $\%$ & 17.5 & 8.7 & 21.7 & 21.7 & 26.1 & 4.3 \\
\hline \multirow{2}{*}{$\begin{array}{c}45 \sim 89^{\circ} \\
\text { 2direction }\end{array}$} & EA & 3 & 2 & 8 & 1 & 5 & 8 \\
\hline & $\%$ & 11.2 & 7.4 & 29.6 & 3.7 & 18.5 & 29.6 \\
\hline \multirow{2}{*}{$\begin{array}{l}90 \sim 134^{\circ} \\
\text { 3direction }\end{array}$} & EA & 6 & 2 & 10 & 3 & 9 & 11 \\
\hline & $\%$ & 14.6 & 4.9 & 24.4 & 7.3 & 22.0 & 26.8 \\
\hline \multirow{2}{*}{$\begin{array}{l}135 \sim 179^{\circ} \\
4 \text { direction }\end{array}$} & EA & 1 & 4 & 3 & 4 & 3 & 6 \\
\hline & $\%$ & 4.8 & 19.0 & 14.3 & 19.0 & 14.3 & 28.6 \\
\hline \multirow{2}{*}{$\begin{array}{l}180 \sim 224^{\circ} \\
5 \text { direction }\end{array}$} & EA & 1 & 1 & 4 & 3 & 0 & 1 \\
\hline & $\%$ & 10,0 & 10.0 & 40.0 & 30.0 & 0 & 10.0 \\
\hline \multirow{2}{*}{$\begin{array}{l}225 \sim 269^{\circ} \\
6 \text { direction }\end{array}$} & EA & 1 & 1 & 0 & 0 & 0 & 0 \\
\hline & $\%$ & 50.0 & 50.0 & 0 & 0 & 0 & 0 \\
\hline \multirow{2}{*}{$\begin{array}{l}270 \sim 314^{\circ} \\
7 \text { direction }\end{array}$} & EA & 1 & 6 & 0 & 0 & 0 & 1 \\
\hline & $\%$ & 12.5 & 75.0 & 0 & 0 & 0 & 12.5 \\
\hline \multirow{2}{*}{$\begin{array}{l}315 \sim 360^{\circ} \\
8 \text { direction }\end{array}$} & EA & 0 & 1 & 1 & 0 & 0 & 2 \\
\hline & $\%$ & 0 & 25.0 & 25.0 & 0 & 0 & 50,0 \\
\hline \multirow{2}{*}{ Total } & EA & 17 & 19 & 31 & 16 & 23 & 30 \\
\hline & $\%$ & 12.4 & 14.0 & 22.8 & 11.8 & 16.9 & 22.1 \\
\hline
\end{tabular}

$61 \sim 90 \mathrm{~cm}$ 는 메타세쿼이아가 11 개, 양버즘나무가 17개, 91 120 $\mathrm{cm}$ 는 메타세쿼이아가 14 개, 양버즘나무가 16개이고 121 150 $\mathrm{cm}$ 는 메타세쿼이아는 11 개, 양버즘나무는 7 개이며, $151 \mathrm{~cm}$ 이 상의 빈도는 메타세쿼이아는 9 개, 양버즘나무는 9 개이다. 메타 세쿼이아의 문정로 48 번길에서의 융기길이는 총 10 주에서 17 개 가 조사되었고 평균길이는 $102.3 \mathrm{~cm}$ 이다. 최대 길이는 $200 \mathrm{~cm}$ 이 
며, 빈도는 $31 \sim 60 \mathrm{~cm}$ 에서 5 개(29.5\%)로 최대값을 가지고 30 $\mathrm{cm}$ 이하의 융기길이는 나타나지 않았다. 둔산로 101 번길에서는 총 10 주에서 19 개가 조사되었으며, 평균길이는 $77.3 \mathrm{~cm}$ 로 메타 세쿼이아 조사대상지 중에 가장 평균값이 낮다. 최대 길이는 $200 \mathrm{~cm}$ 이고, 빈도는 $31 \sim 60 \mathrm{~cm}$ 에서 11 개 $(58.0 \%$ )로 가장 많은 비율로 조사되었으며, $30 \mathrm{~cm}$ 이하는 나타나지 않았다. 둔산북 로90번길은 총 22 주에서 31 개가 조사되었고 평균길이는 $110.4 \mathrm{~cm}$ 로 메타세쿼이아 조사대상지 중 가장 평균값이 높다. 융기길이의 빈도는 $30 \mathrm{~cm}$ 이하에서 1 개(3.3\%)로 가장 낮으며, $91 \sim 120 \mathrm{~cm}$ 에서 8 개 $(25.8 \%)$ 로 가장 높다.

양버즘나무의 한밭대로707번길의 융기길이는 총 9 주에서 16 개의 융기가 조사되었으며, 평균길이는 $101.6 \mathrm{~cm}$, 빈도는 $61 ~ 90$ $\mathrm{cm}$ 에서 7 개 $(43.8 \%)$ 로 최대값을 가지고 $30 \mathrm{~cm}$ 이하의 길이를 가 지고 있는 융기는 나타나지 않는다. 갈마역로에서는 총 14 주에 서 23개의 융기길이를 조사하였고, 평균길이는 $116.7 \mathrm{~cm}$ 으로 양 버즘나무의 조사대상지 중 가장 평균값이 높다. $91 \sim 120 \mathrm{~cm}$ 에 서 6 개(26.0\%)이며, $151 \mathrm{~cm}$ 이상에서 5개(21.8\%), 61 90cm 5 개(21.8\%)으로 대체적으로 융기길이가 높은 급수에 분포되 어 있는 것을 알 수 있다. 유등로는 총 21주에서 30 개가 조사되 었으며, 융기길이의 평균값은 $82.3 \mathrm{~cm}$ 로 가장 낮게 조사되었다. $31 \sim 60 \mathrm{~cm}$ 에서 8 개 $(26.7 \%)$ 로 융기길이가 가장 많이 조사되었 으며, 121 $150 \mathrm{~cm}$ 에서 2 개 $(6.6 \%)$ 로 가장 적은 값을 나타내고 있다. 총 136 개의 융기가 발생하였으며, $31 \sim 120 \mathrm{~cm}$ 에서 약 $68 \%$ 차지하는 것으로 나타났다(Table 9 참조).

Table 9. Uplift length investigation analysis

\begin{tabular}{|c|c|c|c|c|c|c|c|}
\hline \multirow{2}{*}{\multicolumn{2}{|c|}{ Division }} & \multicolumn{3}{|c|}{ Metasequoia glyptostroboides } & \multicolumn{3}{|c|}{ Platanus occidentalis } \\
\hline & & \multirow{2}{*}{$\begin{array}{c}\text { Mun } \\
\text { jeong-ro } \\
48 \text {-gil }\end{array}$} & \multirow{2}{*}{ 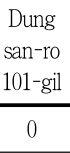 } & \multirow{2}{*}{$\begin{array}{c}\begin{array}{c}\text { Dung } \\
\text { sanbuk-ro } \\
90 \text {-gil }\end{array} \\
1\end{array}$} & \multirow{2}{*}{$\begin{array}{c}\begin{array}{c}\text { Hanbat- } \\
\text { daero } \\
707 \text {-gil }\end{array} \\
0\end{array}$} & \multirow{2}{*}{$\begin{array}{c}\begin{array}{c}\text { Galma- } \\
\text { yeok-ro }\end{array} \\
1\end{array}$} & \multirow{2}{*}{\begin{tabular}{|c} 
Yoo \\
deong-ro
\end{tabular}} \\
\hline Under & EA & & & & & & \\
\hline $30 \mathrm{~cm}$ & $\%$ & 0 & 0 & 3.3 & 0 & 4.3 & 16.7 \\
\hline \multirow{2}{*}{$\begin{array}{c}31 \sim 60 \\
\mathrm{~cm}\end{array}$} & EA & 5 & 11 & 5 & 2 & 4 & 8 \\
\hline & $\%$ & 29.5 & 58.0 & 16.2 & 12.5 & 17.4 & 26.7 \\
\hline \multirow{2}{*}{$\begin{array}{c}61 \sim 90 \\
\mathrm{~cm}\end{array}$} & EA & 3 & 2 & 6 & 7 & 5 & 5 \\
\hline & $\%$ & 17.6 & 10.5 & 19.3 & 43.8 & 21.8 & 16.7 \\
\hline \multirow{2}{*}{$\begin{array}{c}91 \sim 120 \\
\mathrm{~cm}\end{array}$} & EA & 4 & 2 & 8 & 3 & 6 & 7 \\
\hline & $\%$ & 23.5 & 10.5 & 25.8 & 18.7 & 26.0 & 23.3 \\
\hline \multirow{2}{*}{$\begin{array}{c}121 \sim 150 \\
\mathrm{~cm}\end{array}$} & EA & 2 & 2 & 7 & 3 & 2 & 2 \\
\hline & $\%$ & 11.8 & 10.5 & 22.5 & 18.7 & 8.7 & 6.6 \\
\hline \multirow{2}{*}{$\begin{array}{l}\text { Over } \\
151 \mathrm{~cm}\end{array}$} & EA & 3 & 2 & 4 & 1 & 5 & 3 \\
\hline & $\%$ & 17.6 & 10.5 & 12.9 & 6.3 & 21.8 & 10.0 \\
\hline \multicolumn{2}{|c|}{ Average $(\mathrm{cm})$} & 102.3 & 77.3 & 110.4 & 101.6 & 116.7 & 82.3 \\
\hline \multirow{2}{*}{ Total } & EA & 17 & 19 & 31 & 16 & 23 & 30 \\
\hline & $\%$ & 100.0 & 100.0 & 100.0 & 100.0 & 100.0 & 100.0 \\
\hline
\end{tabular}

\section{4) 융기높이}

융기높이를 비교해보면 $3 \mathrm{~cm}$ 이하는 메타세쿼이아가 15 개, 양버즘나무가 17개이며, 3 6cm는 메타세쿼이아가 29개, 양버 즘나무가 32 개로 총 61 개로 발생빈도가 가장 높다. $6 \sim 9 \mathrm{~cm}$ 는 메타세쿼이아가 21개, 양버즘나무가 13 개, 9 12cm는 메타세쿼 이아가 1 개, 양버즘나무가 6 개이며, $12 \mathrm{~cm}$ 이상은 메타세쿼이아 는 1 개, 양버즘나무는 1 개이다.

메타세쿼이아의 문정로 48 번길에서의 융기높이는 총 10 주 에서 17 개가 조사되었고, 평균길이는 $4.7 \mathrm{~cm}$ 이다. 최대 높이는 $8.2 \mathrm{~cm}$ 이며, 빈도는 $6 \sim 9 \mathrm{~cm}$ 에서 4 개(23.5\%)로 최대값을 가지 고 9 $12 \mathrm{~cm}, 12 \mathrm{~cm}$ 이상에서 융기높이는 나타나지 않았다. 둔 산로101번길에서는 총 10 주에서 19 개가 조사되었으며, 평균높 이는 $4.7 \mathrm{~cm}$ 로 메타세쿼이아 조사대상지 중에 문정로 48 번길과 같은 평균높이를 가지고 있다. 최대 높이는 $8.5 \mathrm{~cm}$ 이고 빈도는 6 9cm에서 7개(36.8\%)로 가장 많은 비율로 조사되었으며, 9 $12 \mathrm{~cm}, 12 \mathrm{~cm}$ 이상에서 융기높이는 나타나지 않았다. 둔산북 로90번길은 총 22주에서 31 개가 조사되었고 평균높이는 5.4 $\mathrm{cm}$ 로 메타세쿼이아 조사대상지 중 가장 평균값이 높다. 빈도 는 9 12cm, $12 \mathrm{~cm}$ 이상에서 융기높이 발생이 1 개로 가장 낮으 며, 3 6cm에서 13개(42.0\%)로 가장 높다.

양버즘나무의 한밭대로707번길의 융기높이는 총 9 주에서 16 개의 융기가 조사되었으며, 평균높이는 $6.6 \mathrm{~cm}$ 로 조사대상지 중 가장 평균값이 높다. 빈도의 경우는 $3 \sim 6 \mathrm{~cm}$ 에서 6 개로 최대값 을 가지고 $12 \mathrm{~cm}$ 이상의 길이를 가지고 있는 융기는 나타나지 않아 최소값을 갖는다. 갈마역로에서는 총 14 주에서 23 개의 융기높이를 조사하였고, 평균높이는 $3.6 \mathrm{~cm}$ 으로 양버즘나무의 조사대상지 중 가장 평균값이 낮으면서 조사대상지를 통틀어 가장 융기평균값이 낮다. $3 \sim 6 \mathrm{~cm}$ 에서 14 개(60.8\%)이고, $3 \mathrm{~cm}$ $(34.8 \%)$ 이하가 8 개로 대부분의 융기길이가 낮은 급수에 분포 되어 있는 것을 알 수 있다. 유등로는 총 21 주에서 30 개가 조사 되었으며, 융기높이의 평균값은 $5.1 \mathrm{~cm}$ 로 조사되었다. $3 \sim 6 \mathrm{~cm}$ 에서 12 개(40.0\%)로 융기길이가 가장 많이 조사되었으며, $12 \mathrm{~cm}$ 이상 $(3.3 \%)$ 에서 1개로 가장 적은 값을 나타내고 있다(Table 10 참조).

\section{5) 융기형태}

융기형태 유형은 총 꼬리형, 마운딩형, 불규칙형 총 3 개로 분 류하였으며, 6 곳의 대상지에서 메타세쿼이아 67 주, 양버즘나무 69 주에서 총 136 개의 융기형태가 발생하였고, 꼬리형의 형태는 67 개가 나타났으며, 마운딩형은 50 개, 불규칙형은 19 개가 발생 하여 꼬리형>마운딩형>불규칙형 순으로 빈도가 높음을 알 수 있다.

수종별로 살펴보면 메타세쿼이아는 총 67 개의 융기형태 중 꼬리형이 33 개, 마운딩형이 26 개, 불규칙형이 8 개로 분석되며, 양버즘나무는 총 69 개의 융기형태 중 꼬리형이 34 개, 마운딩형 
Table 10. Uplift height investigation analysis

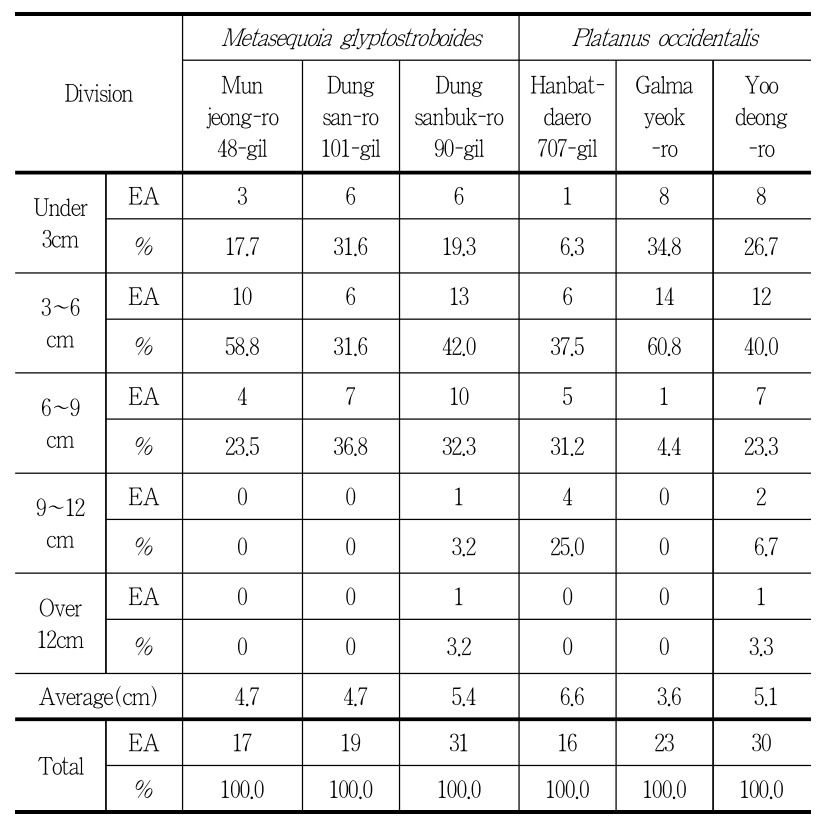

24 개, 불규칙형 11 개로 나타났다.

훙고직경과의 관계를 살펴보면 유등로의 평균 훙고직경은 $37.8 \mathrm{~cm}$ 로 가장 높으며, 둔산북로 90 번길의 평균 흥고직경은 $34.4 \mathrm{~cm}$ 로 두 번째로 높음을 알 수 있는데, 평균 흥고직경이 높 은 조사구역이 융기형태의 빈도도 높은 것을 알 수 있다. 하지 만 갈마역로는 평균흥고직경이 $23.7 \mathrm{~cm}$ 로 가장 규격이 작음에 도 불구하고 세 번째로 융기형태 빈도가 높은 것을 알 수 있다. 이는 갈마역로가 둔산동 아파트단지 사이에 위치함으로써 보 행자들의 통행이 잦고 답압의 문제가 발생, 가로수 식재환경이 양호하지 못하여 근계가 보도 쪽으로 뼏어 융기현상이 발생했다 고 판단되어 개선을 해야 할 구역이라 판단된다(Table 11 참조).

Table 11. Uplift type investigation analysis

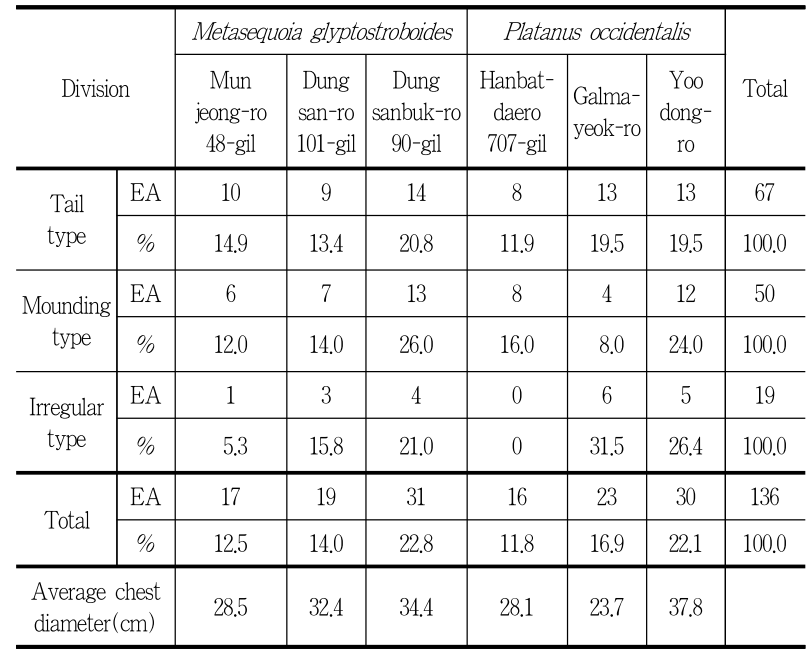

\section{3. 가로수 융기로 인한 시설물 파손현황 및 특성}

가로 물리적 요소 조사의 분석은 보도 폭과 경계석 파손율, 보호틀의 형태, 규격 및 식수대 크기, 파손율, 덮개유무를 조사 한 연구를 토대로 분석하였다.

보도 폭을 수종별 연구대상지로 구분하면 메타세쿼이아의 대상지 중 문정로 48 번길은 10 개소 전 구간 $1.5 \mathrm{~m}$ 이며, 둔산로 101 번길은 자전거도로 $1.5 \mathrm{~m} /$ 보행로 $4.0 \mathrm{~m}$ 구간 3 개소(30.0\%), 보행로 $6.0 \mathrm{~m}$ 구간 7 개소 $(70.0 \%)$ 이며, 둔산북로 90 번길은 자전거 도로 $1.5 \mathrm{~m}$ /보행로 $4.0 \mathrm{~m}$ 구간 20 개소 $(90.9 \%)$, 보행로 $4.0 \mathrm{~m}$ 구간 2 개소 $(9.1 \%)$ 이다. 양버즘나무는 자전거도로와 보행로가 같이 있는 구간은 없었으며 한밭대로707번길은 보도 폭이 전 구간 $4.0 \mathrm{~m}$ 이며 갈마역로 $4.0 \mathrm{~m}$, 유등로 $1.5 \mathrm{~m}$ 이다. 보호틀 형태는 문 정로48번길은 사각형과 말굽형으로 분류되며 사각형은 규격 $1.3 \times 1.1 \mathrm{~m} 4$ 개, $1.2 \times 1.2 \mathrm{~m} 1$ 개, $1.7 \times 1.1 \mathrm{~m}$ 3개로 나누어지며 말굽 형은 규격 $1.3 \times 1.1 \mathrm{~m}$ 2개이다. 둔산로 101 번길은 사각형 $1.2 \times 1.2 \mathrm{~m}$ 6 개, 말굽형 $1.3 \times 1.1 \mathrm{~m}$ 개로 나누어지며, 둔산북로 90 번길은 사 각형 $1.3 \times 1.1 \mathrm{~m} 1$ 개, $1.2 \times 1.2 \mathrm{~m} 4$ 개, $2.7 \times 1.1 \mathrm{~m}$ 8개로 분류되며, 말굽형은 $1.3 \times 1.1 \mathrm{~m}$ 9개로 되어있다. 총 메타세쿼이아의 대상지 보호틀 형태는 사각형 $(1.3 \times 1.1 \mathrm{~m}) 5$ 개, 사각형 $(1.2 \times 1.2 \mathrm{~m}) 11$ 개, 사각형 $(1.7 \times 1.1 \mathrm{~m}) 3$ 개, 사각형 $(2.7 \times 1.1 \mathrm{~m}) 8$ 개, 말굽형 $(1.3 \times 1.1 \mathrm{~m})$ 15 개로 형태가 말굽형인 보호틀의 빈도가 가장 많았으며, $2.7 \times$ $1.1 \mathrm{~m}$ 인 사각형틀이 두 번째로 많았다.

양버즘나무의 가로대상지의 보호틀 형태를 살펴보면 유등로 를 제외한 전 구간이 말굽형으로 되어 있으며 한밭대로707번길 은 규격이 $1.1 \times 1.3 \mathrm{~m}$ 이고 9 주 중 9 개 모두 조성되어 있고, 갈마 역로 역시 규격이 $1.1 \times 1.3 \mathrm{~m}$ 이며 14 주 중 14 개가 조성되어 있다. 유등로는 보호틀 형태가 사각형이며 규격은 $1.2 \times 1.2$ 로 21 주 중 21개가 조성되어 있다.

식수대의 넓이는 먼저 메타세쿼이아의 조사 대상지인 문정 로48번길은 형태가 사각형이며 넓이가 $1.43 \mathrm{~m}^{2}$ 인 보호틀은 4 개, $1.44 \mathrm{~m}^{2}$ 는 1 개, $1.87 \mathrm{~m}^{2} 3$ 개, 형태가 말굽형인 $1.31 \mathrm{~m}^{2}$ 는 2 개이며, 둔산로 101 번길은 형태가 사각형이며 넚이가 $1.44 \mathrm{~m}^{2}$ 인 보호틀 은 6 개, 형태가 말굽형이며 넓이가 $1.31 \mathrm{~m}^{2}$ 인 보호틀은 4 개로 총 2 분류로 조성되어 있으며, 둔산북로 90 번길은 사각형이며 넓 이가 $1.43 \mathrm{~m}^{2} 1$ 개, $1.44 \mathrm{~m}^{2} 4$ 개, $2.97 \mathrm{~m}^{2}$ 8개, 말굽형이며 넓이가 $1.31 \mathrm{~m}^{2}$ 는 9 개로 조성되어 있다. 양버즘나무의 조사 대상지를 살펴보면 한밭대로707번길은 형태가 말굽형이고 식수대 넓이 가 $1.31 \mathrm{~m}^{2}$ 이며 총 9 개로 조성되어 있고, 갈마역로는 말굽형이 고 식수대 넓이가 $1.31 \mathrm{~m}^{2}$ 로 총 14 개, 유등로는 사각형으로 식 수대 넓이가 $1.44 \mathrm{~m}^{2}$ 로 총 21 개가 조성되어 있다.

조사 대상지별 보호틀 파손빈도는 메타세쿼이아 대상지 먼 저 살펴보면 문정로 48 번길은 총 10 개 중 들림 9 개, 깨짐 1 개이 며, 둔산로 101 번길은 총 10 개 중 들림 5 개, 깨짐 2 개, 파손 3 개 이며, 둔산북로 90 번길은 총 22 개 중 들림 9 개, 깨짐 3 개, 파손 6 
개이며 유일하게 양호한 보호틀이 4 개 있었다. 양버즘나무의 대상지를 살펴보면 한밭대로707번길은 총 9 개 중 들림 5 개, 깨 짐 3 개, 파손 1 개이며, 갈마역로는 총 14 개 중 들림 11 개, 깨짐 4 개이며, 유등로는 총 21 개의 사각형 보호틀 중 들림 12 개, 깨 짐 2 개, 파손 7 개가 조사되었다.

차도경계석 파손율을 살펴보면 메타세쿼이아의 문정로 48 번 길은 차도경계석이 전 구간 양호하였으며, 둔산로 101 번길은 10 개 중 3 개가 들림 현상이 나타났으며, 둔산북로 90 번길은 22 개 중 5 개가 들림 현상이 조사되었다. 양버즘나무의 한밭대로707 번길은 9 개 중 전 구간 양호하였으며, 갈마역로는 14 개 중 1 개 가 들림 현상이 일어났으며, 유등로는 21 개 중 10 개가 들림 현 상이 일어난 것으로 조사되었다.

이는 수목 보호틀의 파손빈도를 비교하였을 때 차도경계석 파손율은 비교적 적게 나타난 것을 알 수 있으며, 비중이 높고 경계석기반조성이 견고하게 된 차도경계석으로 근계가 뻗질 못하는 것으로 판단되며 이론적 고찰 결과 수분과 양분이 풍부 한 방향으로 뿌리가 이동하는 습성도 작용된 것으로 판단된다. 문정로 48 번길과 유등로의 도로폭이 $1.5 \mathrm{~m}$ 로 같으나 문정로 48 번 길은 전 구간 양호하지만 유등로는 21 개소 중 10 개소가 들림 현상이 나타난 것으로 보아 보도 폭과 보호틀 및 차도경계석 파손율과는 연관성이 적은 것으로 판단되어 좀 더 구체적인 연 구가 필요하다. 또한 보호덮개의 유무가 뿌리 들뜸 현상으로 인한 포장면 융기와 답압과의 밀접한 관계가 있다고 예상되며 앞으로 보호덮개에 관한 연구가 더욱 활성화되기를 기대한다 (Table 12 참조).

\section{4. 보도포장 변형량 산정}

보도포장 변형량은 수목별 융기길이 및 너비, 융기높이, 융 기형태를 종합하여 나타낸 값으로 개별 포장 변형 면적에 융기 높이를 곱하여 상대값을 구하였다. 또한 융기형태가 2개 이상 일 경우 각각 변형량 값을 구하고 합하였다(Ahn, 2014).

메타세쿼이아의 조사대상지 3 곳 중 문정로 48 번길은 10 주에 서 $0.62 \mathrm{~m}^{3}$ 의 변형량이 나타났으며, 둔산로 101 번길은 10 주에서 $0.437 \mathrm{~m}^{3}$, 둔산북로 90 번길은 22 주에서 $0.952 \mathrm{~m}^{3}$ 로 나타났다. 메타 세쿼이아의 최소 변형량은 둔산로 101 번길에 위치한 흉고직경 이 $24 \mathrm{~cm}$ 이며, 식재간 거리가 $9 \mathrm{~m}$ 이고 식재위치는 2 열 식재, 보 호틀은 $1.2 \times 1.2 \mathrm{~m}$ 규격의 화강석/콘크리트 재질인 사각형이고 보도 폭은 $6 \mathrm{~m}$ 인 시설 현황에 융기길이는 $38 \mathrm{~cm}$, 너비는 $30 \mathrm{~cm}$, 높이는 $1.3 \mathrm{~cm}$ 인 꼬리형 형태를 가진 $0.00148 \mathrm{~m}^{3}$ 의 변형량 값을 가졌으며, 최대 변형량은 둔산북로90번길에 위치한 흉고직경 $48 \mathrm{~cm}$, 식재간 거리가 $6 \mathrm{~m}$ 이고 1 열 식재이며, 보호틀은 화강석/ 콘크리트 재질로 된 $1.1 \times 1.3 \mathrm{~m}$ 규격의 말굽형이고 자전거도로 $1.5 \mathrm{~m}$, 보도 $4 \mathrm{~m}$ 의 폭이 조성되어 있으며, 융기길이는 $130 \mathrm{~cm}$, 너 비는 $110 \mathrm{~cm}$, 높이는 $15.1 \mathrm{~cm}$ 인 마운딩 형태를 가진 $0.216 \mathrm{~m}^{3}$ 의 변형량 값을 가졌다.

양버즘나무의 변형량을 살펴보면 조사대상지 3 곳 중 한밭대 로707번길은 9 주에서 $0.558 \mathrm{~m}^{3}$ 의 변형량이 나타났으며, 갈마역 로는 14 주에서 $0.382 \mathrm{~m}^{3}$, 유등로는 21 주에서 $0.551 \mathrm{~m}^{3}$ 로 나타났 다. 양버즘나무의 최소 변형량은 유등로에 위치하고 흥고직경 $43 \mathrm{~cm}$, 식재간 거리가 $8 \mathrm{~m}$ 이며, 식재위치는 1 열 식재이고 보호

Table 12. Street furniture breakdown and characteristics

\begin{tabular}{|c|c|c|c|c|c|c|}
\hline \multirow{2}{*}{ Division } & \multicolumn{3}{|c|}{ Metasequoia glyptostroboides } & \multicolumn{3}{|c|}{ Platanus occidentalis } \\
\hline & Munjeong-ro 48-gil & Dungsan-ro 101-gil & Dungsanbuk-ro 90-gil & Hanbat-daero 707-gil & Galmayeok-ro & Yoodong-ro \\
\hline 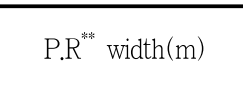 & 1.5 & $\begin{array}{c}\text { B.R }^{* * *} / P . R^{* *}: 1.5 / 4.0 \\
\text { Only P.R. } 6.0\end{array}$ & $\begin{array}{c}\text { B.R. }^{* * *} / \text { P.R. }^{* *}: 1.5 / 4.0 \\
\text { Only P.R.: } 4.0\end{array}$ & 4.0 & 4.0 & 1.5 \\
\hline $\begin{array}{l}\text { Protection frame type } \\
(\mathrm{m})\end{array}$ & $\begin{array}{c}\text { Square } \\
1.3 \times 1.1: 4 \\
1.2 \times 1.2: 1 \\
1.7 \times 1.1: 3 \\
\text { Horseshoe } \\
1.3 \times 1.1: 2\end{array}$ & $\begin{array}{c}\text { Square } \\
1.2 \times 1.2: 6 \\
\text { Horseshoe } \\
1.3 \times 1.1: 4\end{array}$ & $\begin{array}{c}\text { Square } \\
1.3 \times 1.1: 1 \\
1.2 \times 1.2: 4 \\
2.7 \times 1.1: 8 \\
\text { Horseshoe } \\
1.3 \times 1.1: 9\end{array}$ & $\begin{array}{l}\text { Horseshoe } \\
1.1 \times 1.3: 9\end{array}$ & $\begin{array}{l}\text { Horseshoe } \\
1.1 \times 1.3: 14\end{array}$ & $\begin{array}{c}\text { Square } \\
12 \times 1.2: 21\end{array}$ \\
\hline $\begin{array}{c}\text { Protection } \\
\text { frame breakage }\end{array}$ & $\begin{array}{c}\text { Lifted }(9 / 10) \\
\text { Fracture }(1 / 10)\end{array}$ & $\begin{array}{c}\text { Lifted(5/10) } \\
\text { Fracture(2/10) } \\
\text { Damage(3/10) }\end{array}$ & $\begin{array}{c}\text { Lifted }(9 / 22) \\
\text { Fracture(3/22) } \\
\text { Damage(6/22) } \\
\text { Good(4/22) }\end{array}$ & $\begin{array}{c}\text { Lifted(5/9) } \\
\text { Fracture(3/9) } \\
\text { Damage(1/9) }\end{array}$ & $\begin{array}{l}\text { Lifted(11/14) } \\
\text { Fracture(4/14) }\end{array}$ & $\begin{array}{c}\text { Lifted(12/21) } \\
\text { Fracture(2/21) } \\
\text { Damage (7/21) }\end{array}$ \\
\hline Plant area width $\left(\mathrm{m}^{2}\right)$ & $\begin{array}{l}1.43,1.44 \\
1.87,1.31 \\
\end{array}$ & $\begin{array}{l}1.44 \\
1.31 \\
\end{array}$ & $\begin{array}{l}1.43,1.44 \\
2.97,1.31 \\
\end{array}$ & 1.31 & 1.31 & 1.44 \\
\hline Protective cover & $\begin{array}{l}\text { Existence }(1 / 10) \\
\text { Non }(9 / 10)\end{array}$ & Non & Non & Non & Non & Non \\
\hline $\begin{array}{l}\text { Driveway boundary } \\
\text { stone breakage }\end{array}$ & $\begin{array}{c}\text { Good: } 100.0 \% \\
(0 / 10)\end{array}$ & $\begin{array}{l}\text { Lifted: } 30.0 \% \\
\quad(3 / 10)\end{array}$ & $\begin{array}{l}\text { Lifted: } 22.7 \% \\
\quad(5 / 22)\end{array}$ & $\begin{array}{c}\text { Good: } 100.0 \% \\
(0 / 9)\end{array}$ & $\begin{array}{l}\text { Lifted: } 7.1 \% \\
\quad(1 / 14)\end{array}$ & $\begin{array}{l}\text { Lifted: } 47.6 \% \\
\quad(10 / 21)\end{array}$ \\
\hline
\end{tabular}

P.R.: Pedestrian road, ${ }^{* * *}$ B.R.: Bicycle road 
틀은 화강석/콘크리트의 재질인 $1.2 \times 1.2 \mathrm{~m}$ 규격의 사각형이며, 보도 폭은 $1.5 \mathrm{~m}$ 이고 융기길이는 $30 \mathrm{~cm}$, 너비는 $13 \mathrm{~cm}$, 높이는 $2.3 \mathrm{~cm}$ 인 꼬리형 형태를 가진 $0.0009 \mathrm{~m}^{3}$ 의 변형량 값을 가졌다. 또한 최대 변형량을 가진 구간은 한밭대로707번길이고 흥고직 경 $29 \mathrm{~cm}$, 식재 간 거리가 $8 \mathrm{~m}$ 이고, 1 열 식재이며 보호틀은 화강 석/콘크리트 재질로 된 $1.1 \times 1.3 \mathrm{~m}$ 규격의 말굽형이고 $4 \mathrm{~m}$ 의 보 도 폭이 조성되어 있으며 융기길이는 $140 \mathrm{~cm}$, 너비는 $80 \mathrm{~cm}$, 높 이는 $10.2 \mathrm{~cm}$ 인 꼬리 형태를 가진 $0.114 \mathrm{~m}^{3}$ 의 변형량 값을 가졌 다.

흥고직경과의 변형량 값을 종합.분석해보면 메타세쿼이아의 대상지인 문정로 48 번길은 평균 흥고직경이 $28.5 \mathrm{~cm}$, 둔산로 101 번길은 $32.4 \mathrm{~cm}$, 둔산북로 90 번길은 $34.4 \mathrm{~cm}$ 이고, 양버즘나무의 대상지인 한밭대로 707 번길의 평균흉고직경은 $28.1 \mathrm{~cm}$, 갈마역 로는 $23.7 \mathrm{~cm}$, 유등로는 $37.8 \mathrm{~cm}$ 이며, 이를 Table 11 과 비교를 해보면 가로수 흉고직경과 융기 변형량과의 상관성이 적다는 결과를 도출할 수 있었는데, 이는 흥고직경보다는 가로현황 및 물리적 요소, 주변가로환경에 의해서 변형량 값의 결정이 더 크게 작용된다는 것을 알 수 있었다(Table 13 참조).

\section{V. 결론}

본 연구는 가로수 뿌리 들뜸으로 인한 보도 포장면 융기현상 의 특성을 조사·분석하여 최초 가로수조성 시 규격 흥고직경 $8 \mathrm{~cm}$ 로 식재한 후(경과기간 약 20년 후)에 가로수의 융기특성 상태를 연구하는데 목적이 있으며, 보도포장면의 변형량에 따 른 원인 및 문제점을 도출하여 쾌적한 가로 보행 환경과 가로 수 식재환경을 위한 개선방안을 제시하고자 한다. 연구범위는 대전광역시 서구 일대에 조성된 가로수인 메타세쿼이아와 양버 즘나무의 뿌리 들뜸 현상으로 인한 보도 포장면 융기현상이 발 생한 곳 6 곳을 선정하여 이론적 고찰 및 선행연구, 현장조사 및 분석을 통한 연구결과를 요약하면 다음과 같다.

첫째, 연구 대상지는 대전광역시 서구 둔산동 택지개발(1990 1994) 당시 조성된 가로수를 중심으로 융기현상이 발생한 곳을 구청자료 검토 및 예비답사를 통하여 선정하였다. 대상지 6 곳 을 수종별로 요약하면 메타세쿼이아는 문정로48번길 29주, 둔 산로101번길 58주, 둔산북로 90 번길 73 주로 총 160 주이며, 평균 흥고직경은 $32.4 \mathrm{~cm}$ 이다. 양버즘나무는 갈마역로 48 주, 한밭대 로707번길 38 주, 유등로 62 주로 총 148 주이며, 평균흉고직경은 $30.9 \mathrm{~cm}$ 이다. 총 308 주의 가로수 중 최근 5 년 이내에 뿌리 들뜸
개선공사를 실시하지 않은 가로수를 바탕으로 연구하였으며, 메 타세쿼이아 42 주, 양버즘나무 44 주가 가로 융기현상이 발생한 것으로 조사되었다.

둘째, 식재간 거리는 6 8m를 기준으로 간격을 조정할 수 있 다는 이론적 고찰에 부합하여 대체적으로 틀에서 벗어나지 않 게 식재간 거리가 갖추어져 있으며, 연구대상지 내 가로 물리 적 요소 특성은 연구대상지에서 가로수 보호틀 파손율 $(95.3 \%)$ 이 차도경계석 파손율(19.7\%)보다 현저하게 높게 나타나는 것 을 알 수 있었고 형태는 사각형이며, 규격이 $2.7 \times 1.1 \mathrm{~m}$ 인 보호 틀의 양호율이 가장 높아 식수대면적이 일정 이상 높아지면 보 호틀 파손빈도가 낮아지는 것을 알 수 있다. 또한 보도 폭과 보 호틀, 차도경계석 파손율과는 연관성이 적은 것으로 판단되어 좀 더 구체적인 연구가 필요하다. 보호덮개는 포장면 융기현상 이 확인된 총 86 개의 가로수 중 1 개만 존재하고, 85 개는 존재 하지 않은 것으로 확인되어 보호덮개가 없는 가로수는 포장면 융기현상 발생 확률이 높다는 것으로 판단된다. 또한 본 연구 에서는 가로수 흉고직경과 융기 변형량과의 상관성이 적다는 결과를 도출할 수 있었으며, 이는 훙고직경보다는 가로현황 및 물리적 요소, 주변가로환경에 의해서 변형량 값의 결정이 더 크게 작용된다는 것을 알 수 있었고, 좀 더 많은 양의 가로수를 조사- 분석하여 체계적이며 방대한 자료를 가지고 심도 깊은 연구가 필요하다고 판단된다.

셋째, 보도 포장면 융기특성 중 융기방향 및 형태는 꼬리형> 마운딩형>불규칙형 순으로 꼬리형에 1 개의 융기가 가장 많이 발생하였으며, 각도는 차도경계석과 평행으로 차도방향이 $180^{\circ}$, 보도방향이 $90^{\circ}$ 로 기준하였을 때 1 방향 $\left(0 \sim 44^{\circ}\right), 2$ 방향( $\left.45 \sim 89^{\circ}\right)$, 3 방향 $\left(90 \sim 134^{\circ}\right)$ 에서 가장 많은 포장면 융기발생이 일어났다. 이는 가로수가 대부분 1 열 식재로 되어 있어 차도경계석의 기 초다짐방향으로 뿌리확장에 제한이 있어 다른 방향으로 뿌리 가 뺃게 되어 들뜸 현상이 일어나며, 특히 2 방향, 3 방향에 포 장면 융기현상이 집중되어 있는 것으로 볼 때 보행자 통행 시 지반 답압으로 인한 영양분 및 수분부족으로 1 방향, 4 방향보 다 더욱 융기현상이 집중적으로 발생하였다고 판단되었으며, 융기길이는 약 31 60cm에서 융기발생이 가장 많이 발생하고, 융기높이는 3 6cm에서 발생빈도가 가장 높다. 이를 통해 융 기길이와 높이는 조성 후 약 20년 후 융기 진행 상태를 파악 할 수 있었다.

넷째, 융기 변형량 결과를 비교해보면 조사 주수가 메타세쿼 이아가 양버즘나무보다 2주 적음에도 불구하고 양버즘나무의

Table 13. Uplift deformation investigation analysis $\left(\mathrm{m}^{3}\right)$

\begin{tabular}{c|c|c|c|c|c|c|c}
\hline Division & Munjeong-ro 48-gil & Dungsan-ro 101-gil & Dungsanbuk-ro 90-gil & Hanbat-daero 707-gil & Galmayeok-ro & Yoodong-ro & Total \\
\hline Metasequoia glyptostroboides & 0.62 & 0.437 & 0.952 & $\cdot$ & $\cdot$ & $\cdot$ & 2.009 \\
\hline Platanus occidentalis & $\cdot$ & $\cdot$ & $\cdot$ & 0.558 & 0.382 & 0.551 & 1.491 \\
\hline
\end{tabular}


변형량 보다 약 1.3 배 정도 높게 나타났는데, 이것은 메타세쿼 이아가 양버즘나무보다 포장면 융기로 인한 변형량이 높다는 것을 알 수 있었다. 또한 융기길이, 융기너비, 융기높이가 클수 록 변형량이 높아지는 것을 알 수 있었다. 이는 흉고직경, 보도 폭의 규격과 융기현상의 빈도, 변형량의 관계는 꼭 비례하지 않으며, 토양습도와 식재 기반 등 외부적인 요소로 인해 차이 가 있다고 판단되어 융기현상을 저감하기 위한 개선방안이 필 요하다.

본 연구를 통하여 뿌리 들뜸으로 인한 가로융기현상에 대하 여 보다 실질적인 대비책을 마련하고, 도시미관의 증진과 보행 환경개선을 기대한다. 또한 융기발생이 연구에서 제시한 가로 수생육과 가로 물리적인 요소뿐만 아니라, 여러 가지 원인이 있 음에도 불구하고 제한적인 조사요소를 가지고 연구를 한 점이 아쉬우며, 대상수종을 2 종으로 선정하고 총 6 곳의 가로수 길 에서 308 주를 조사하여 86 주의 대상수목에 136 개의 융기현상 을 조사하여 연구결과를 도출해내었지만, 앞으로 추가 연구가 진행되어 좀 더 넓은 조사범위에서 체계적이고 구체적으로
심도 높은 융기에 대한 후속연구가 필요하다.

\section{References}

1. Ahn, S. H.(2014) A Study on the Characteristics of Pavement Uplift by Growth of Street Tree. Master's Thesis, Seoul City University. Korea.

2. Asan city(2016) Street Tree Composition and Management Ordinance.

3. Hong, S. H., S. J. Yang, S. H. Choi, J. B. Baek and S. D. Lee(2012) Growing characteristics of shrub in the planting strip of street, Busan City, Korea. Korean Journal of Environment and Ecology 26(2): 257-263.

4. Lee. K. J.(2011) 수목생리학. Seoul Univercity Publisher.

5. Noburu karizumi(1979) The Latest Illustrations of Tree Roots. 誠文 堂新光社.

6. http://www.forest.go.kr

7. http://www.kgnews.co.kr/news/articleView.html?idxno $=493141$

8. http://map.naver.com

9. http://www.namu.wiki

10. http://www.nibr.go.kr 